\title{
Blue governance: Sustainable port governance
}

\author{
Beatriz López-Bermúdez*/ María Jesús Freire-Seoane / Carlos Pateiro-Rodríguez \\ Universidade da Coruña - Facultade de Economía e Empresa
}

Received: 23 June 2020 / Accepted: 1 September 2020

\begin{abstract}
This research presents a proposal for a study of governance from the perspective presented in the Integrated Maritime Policy (IMP) of the European Union, which seeks to provide coherence to the problems in the maritime sector through the coordination of all stakeholders in the maritime sector. The objective of this research is to identify the barriers and the problems that occur when a Member State tries to implement the Integrated Maritime Policy in the governmental organization of marine spaces. The challenge is to achieve 'blue governance' i.e.the activation of a network of cooperation between the different stakeholders of the port sectors so as to be able to integrate the different regional, national, European and international levels with the purpose of establishing a structured, systematic collaboration framework.
\end{abstract}

\section{Keywords}

Blue growth / Blue Economy / European Union / Integrated Maritime Policy/ Stakeholders.

\section{Gobernanza azul: gobernanza portuaria sostible}

\section{Resumo}

Esta investigación ofrece unha proposta para o estudo da gobernanza desde a perspectiva presentada na Política Marítima Integrada (PMI) da Unión Europea, que busca proporcionarlles coherencia aos problemas do sector marítimo desde a coordinación de todos os interesados. 0 obxectivo desta investigación é identificar as barreiras e os problemas que ocorren cando un Estado membro intenta implementar a Política Marítima Integrada na organización gobernamental de espazos mariños. 0 desafío que se tenta conseguir é lograr a gobernanza azul, é dicir, a activación dunha rede de cooperación entre as diferentes partes interesadas do sector portuario para poder integrar os diferentes niveis rexionais, nacionais, europeos e internacionais de cara a unha estrutura colaborativa.

Palabras clave

Crecemento azul / Economía azul / Unión Europea / Política Marítima Integrada / Stakeholders.

JEL Codes: H7, R11, N74.

\section{Introduction}

The port, as a maritime services infrastructure, has evolved in its functions over the years to become a complex logistic node within the multimodal chain of freight transport. European ports are of great importance and the European Commission identifies them as key pieces both in the development of trade within the European Union (Comisión Europea, 2013), and in its economic growth. The ports are border points that connect different markets through maritime transport. For all these reasons, it can be said that the port as such or, being more precise, the port area, is a physical space with competences in both terrestrial and maritime space, which are of great complexity, considering all the operations that are carried out within it.

The concept of Port Governance arises in response to the need for ports to have a clear organizational structure that allows efficient management in the transport service, both of goods and

\footnotetext{
${ }^{*}$ Corresponding author: beatriz.lopez2@udc.es
} 
passengers. Rodrigue, Comtois \& Slack (2013) delves into the subject and indicates that the concept of governance is essential to define the function of a port. The classifications that have been formulated on the theoretical plane have only considered the governance scheme from the merchant's point of view i.e. from the perspective of freight transport. The World Bank (2007) publishes the Port reform: Toolkit, which proposes, for the first time, a simple, clear and homogeneous classification of port governance, in which it tries to identify whether the person in charge of carrying out a series of port activities is a public or private entity. Under this hypothesis, the results are four models of port governance: public service port, tool port, landlord port and private service port.

In the tool port model, the public sector is the owner of the infrastructure and in charge of the operation and management of the port, but it also provides some operational services, such as stevedoring, piloting, supply, storage, etc., to legal business units which may be partly state-owned or purely private. Some Latin American countries have used this intermediate modality to exercise port governance during the transition periods between the enactment of port modernization laws, which in some cases can last up to ten years, and the implementation of the new management.

In the landlord model, a state entity is the owner of the land (individual Port Authority or supralocal agency/institution), assigning through a concession contract, the exploitation and management of port infrastructures to a second entity, which may be a private, public or mixed company, depending on the legislation applicable to the case (Cabrera, Suárez-Alemán \& Trujillo, 2015). The transition from the tool port model to the landlord model takes place in the 1980s, and is typical of the countries of the European Union (Hoffmann, 1999), as well as the port system of the countries that make up the North American Free Trade Agreement (NAFTA) (Fawcett, 2006).

The private service port model consists of the privatization of all elements, including land ownership, with only the public sector retaining standard regulatory supervisory power. The first case of application of this model took place in 1981 with the privatization of all British ports under the control of the Associated British Ports Holding (Pettit \& Beresford, 2008). Currently, it is possible to cite other countries where there are governance tensions that tend to favor the total privatization of the service; among others, Argentina, Chile, Colombia, Malaysia, Mexico, New Zealand, the Philippines and Venezuela (Pettit \& Beresford, 2008).

For the moment, the Integrated Maritime Policy of the European Union has not explicitly made any reference in relation to port governance. However, the maritime basins claim, as part of their strategies, that there is an urgent need to align and clarify the governance system of each member country, as well as the competences of each institution/body. In other words, for the sea basins to carry out a coordinated strategy more clarity is necessary in the port system of each country, indicating the corresponding institutions, levels and competencies. For this reason it is necessary to redesign not only the strategies, but the institutions themselves, so that they act accordingly and incorporate the wide range of opportunities that arise with the emergence of digitization as a catalyst element of the new environmental objectives (Nikolopoulou et al., 2019; Notteboom \& Neyens, 2017).

The objective of this paper is to identify the difficulties that result from a disorderly organization, difficulties which become patent when trying to implement the Integrated Maritime Policy in the organization of the marine spaces. The challenge is to achieve a system of governance which is vertebrated as a network of cooperation between the different stakeholders of the port sectors, so that the different regional, national, European and international levels can be integrated for a better structured and more systematic collaboration. This way, we review the functions that must be present in the port system of a member state, the green objectives with which it must be aligned, and a proposal of indicators that will be able to evaluate the organization of the port authority according to the total traffic. Finally, we try to introduce two indicators for evaluation of both of port performance and institutional organization.

This paper is structured as follows: the introduction; Section 2, which develops a literature review about port governance; Section 3, which introduces the issue of sustainability in maritime transport; Section 4, which provides the green port objectives i.e., the intersection between port governance and 
sustainability; Section 5, which presents the indicators applied to two Galician port authorities; and finally, the conclusions and the bibliographical references.

\section{Port and port governance}

The ports are part of the territory of the States, and control over them can be exerted by state agencies or decentralized entities, depending on how the legal distribution of powers has been established.

The background of the new models of port governance takes the privatization model of the United Kingdom as a starting point. In this country, the devolution process has been implemented since 1945 and numerous researchers have delved into the study of this port regulation, in particular, Baird (1995, 1999, 2000), Goss (1998), Baird \& Valentine (2006) and Pettit \& Beresford (2008). The issue of port governance has gained more interest in the research area since 2000, as it was as of this year that the number of research works increased considerably. It is also from then on that the needs that arise in maritime transport allow the port authorities to begin to identify problems that must be solved via an improvement in their organizational structures beyond more privatization initiatives, promoting a broad debate and new research on this matter.

In this period, academic publications are mainly focused on European countries. In the case of Greece, we can point out the study carried out by Pallis \& Syriopoulos (2007), which includes the reform that was carried out in relation to port governance at the end of the 1990s. The main twelve Ports of national interest were transformed from "public law companies" into state-owned port corporations. Responsibility for port governance was transferred to the autonomous commercial management port authorities. At a later stage, two ports (Piraeus and Thessaloniki) were included in the Athens Stock Exchange. Based on the discussions on the port performance indicators, this study examines the financial development of this new model of port governance. It does so through an empirical evaluation of the financial situation of the 12 port entities during a period that corresponds to the reorganization of the sector. The analysis suggests that certain rigidities are still present and that it is necessary to take more additional modernization and restructuring steps. Despite the profitable financial results for most Greek ports of national interest, the examination of the financial accounts raises considerable doubts about the efficiency of the organizational structures of the ports, currently in the phase of development transition. These results are in line with the suggestions that port governance in Greece does not yet respond to any of the possible configurations of structures and strategies that improve port competitiveness, and that have been identified in the port literature.

Among the research carried out on Italian ports (Ferrari, Tei \& Merk, 2015; Valleri, Lamonarca \& Papa, 2006), the analysis by Ferrari et al. (2015), whose main objective is European port regulation, focuses mainly on the effectiveness of concession agreements in the port sector. It is widely recognized that the current heterogeneity in port regulation in the European Union is having an impact on the competitiveness of the ports. Furthermore, port authorities must consider a wide range of objectives to manage interactions with private operators responsible for port activities. This document discusses how the concession agreement specifications can help regulate these licenses.

Regarding the Spanish ports, we can highlight (Castillo-Manzano \& Asencio-Flores, 2012; González Laxe, 2012; Martínez-Budría, Díaz-Armas, Navarro-Ibáñez \& Ravelo-Mesa, 1999) among the most relevant papers, the study by Castillo-Manzano \& Asencio-Flores (2012), whose objective is to analyze the interaction between the port devolution processes in Spain and Portugal in their common geographic environment, - the Iberian Peninsula. First, a review is performed of the different port devolution processes in the world including a specific analysis of the transition of numerous public and centralized ports to the "landlord" model. Among the conclusions that we can highlight regarding the Iberian port systems is the need for a process of reflection before any change in the model of port governance, and greater cooperation between the two countries to avoid any possible price wars in the future. The overinvestment process that the devolution process has generated, especially in 
Spanish ports, should also be mentioned, to highlight once again the almost inexhaustible capacity of ports to absorb public funds for investments that do not take profitability into account.

In the case of Portugal, the research by Marques \& Fonseca (2010) analyzes the market structure, the privatization model and the regulation of port operations. The regulation of the port sector in Portugal is developed at three levels. The first refers to contract regulation (first level) that establishes rules (rights and duties) for concessionaires. These entities in turn are also supervised by the port authorities (second level) that are responsible for everything that happens under their jurisdiction. Finally, there is a national regulatory agency (third level) that has powers throughout the sector, including port authorities and concessionaires. These three visible hands try to minimize market failures and be proactive in the growth and development of the Portuguese port sector. This document presents the Portuguese port sector, examining in detail the contracts with the private sector and the current regulatory model.

It also suggests various measures to improve the regulatory process. In other European countries such as Belgium (Meersman, van de Voorde \& Vanelslander, 2006), Ireland (Brunt, 2000) or Poland (Zurek, 1997), research has been carried out on this matter. It is worth highlighting the research by De Langen \& van der Lugt (2006), where the governance structures of the port authorities of the main Dutch seaports are analyzed. This specification is based on a framework to assess the fit between the environment, governance model, strategy and capabilities of the port authority. Changes in the port environment have caused changes in the governance model and strategy of seaports. For the three main Dutch seaports, regional cooperation with surrounding ports and efforts to professionalize the port authority are important issues. In addition, the three ports are developing new activities to play a more active role in improving the port's competitiveness.

Oral, Kisi, Cerit, Tuna \& Esmer (2006), analyze the ports of Turkey, highlighting their strategic position between Asia and Europe as a land bridge in north-south and east-west transport, and therefore, placing the ports as nodes of vital importance for the efficiency of activity logistics of the country. Although Turkey has a strategic position in terms of logistics and transportation, its roughly 160 ports do not enjoy the usual benefits of ports. Ports and piers can be classified in terms of whether they are operated by the public sector, the affiliated sector, regional municipalities, or the private sector. This document focuses on Turkey's port administration and management system and the possibilities of applying good governance in Turkish ports during the current privatization process of public ports. It concludes that the privatization process has not yet been completed and that there are many legal and practical issues to be resolved.

Currently, an effort to manage an in-depth improvement of the organization of the offer of port services is still under way, and more specifically in relation to the functions carried out by the different maritime authorities, since these represent the greatest meeting point between the operators that carry out the daily operations and the entities in charge of the regulatory development.

Verhoeven (2010) points out that there are certain factors, such as the pressure of the different stakeholders that are part of the supply chain, where the port is presented as a logistics node par excellence. This theory focuses on whether port authorities should conduct port management from the perspective of enforcing the law and regulatory regulation, or only from a free-market perspective, being one more actor. Heaver, Meersman, Moglia \& van de Voorde (2000) identify in their study three possible roles for port authorities: (a) become part of the supply chain, which is identified, in this case, as being a stakeholder; (b) stay in a support position; (c) disappear.

Verhoeven (2010) also analyzes the functions of the Baltazar \& Brooks matrix (Baltazar \& Brooks, 2001) i.e.owner, regulator and operator. In this case, each function needs a detailed analysis and an individualized study of the actions to be carried out and of the areas of action, especially when it comes to solving the problems they face. With this information, the port authority renaissance matrix is generated. In this matrix, the community manager is added, a function which can be identified with the cluster manager of De Langen \& Pallis (2007), and which registers the port in an environment of path dependence (Notteboom, De Langen \& Jacobs, 2013) and of competition approaches (Lee \& Song, 
2010), where it acts as transformation node within the logistics chain, both in the hinterland and in the foreland.

Table 1 presents the port authority renaissance matrix in its field of action of an entrepreneurial nature (Verhoeven, 2010).

Table 1. New governance actions

\begin{tabular}{|c|c|}
\hline Landlord & $\begin{array}{l}\text { 1. Real estate developer: } \\
\text { - Continuity, maintenance and improvement. } \\
\text { - Direct investor. } \\
\text { - Urban and environmental development. } \\
\text { - Financial income based on commercialization of in-movable assets. } \\
\text { - Financial income from non-essential activities. } \\
\text { 2. B2B direct negotiations in the search for new market niches. } \\
\text { 3. Direct investments in inland ports, dry ports and other ports. }\end{array}$ \\
\hline Regulator & $\begin{array}{l}\text { 1. Active application of and compliance with the rules and regulations through cooperation with } \\
\text { local, regional and national agents, as well as establishing their own rules. } \\
\text { 2. Intermediate and help the port community to comply with the rules and regulations. } \\
\text { 3. Financial income that have nothing to do with thedifferent regulatory functions depending on } \\
\text { sustainability reasons. }\end{array}$ \\
\hline Operators & $\begin{array}{l}\text { 1. Dynamic use of the concession policy in combination with the real estate brokerage function. } \\
\text { 2. Shareholder of private port services. } \\
\text { 3. It provides services of general economic interest and specialized commercial services. } \\
\text { 4. Provides services in other ports. }\end{array}$ \\
\hline $\begin{array}{l}\text { Community } \\
\text { manager }\end{array}$ & $\begin{array}{l}\text { 1. Economic dimension (greater direct commercial participation): } \\
\text { - Resolves hinterland bottlenecks. } \\
\text { - Provide training and practice. } \\
\text { - Provide ICT services. } \\
\text { - Advertising } \\
\text { - or "lobbying". } \\
\text { 2. Social dimension: } \\
\text { - Resolves conflicts of interests } \\
\text { - or "lobbying" } \\
\text { - or provides positive externalities. }\end{array}$ \\
\hline
\end{tabular}

Source: Verhoeven (2010).

\section{Sustainable maritime transport policies in Europe}

Environmental sustainability describes a broad concept that is backed by "eco-friendly" production and an efficient use of resources in order to mitigate and avoid the negative impact on future generations. The concern for the environment, or rather, the definition of sustainable development appears for the first time in the report Our common future, where Gro Harlem Brundtland defines sustainability as production that 'meets the needs of the present without compromising the needs of future generations'. This report was the result of the World Commission on Environment and Development of the United Nations in 1983. In 1992, the Commission for Sustainable Development was created within the United Nations with the purpose of making the agreed measures a reality at the United Nations Conference on Environment and Development, known as the Earth Summit, where Agenda 21 was approved (Rio de Janeiro, Brazil).

In 1993, the European Maritime Ports Organization (hereinafter, ESPO) was founded. It is constituted as the representative body of the stakeholders that make up the harbor cluster of the seaports of the Member States of the European Union and Norway. This institution created, a Code of 
Environmental Conduct for Industrial Ports (Goulielmos, 2000) in 1994, which was modified in 2003 as a result of legislative changes within the European Union. It is at this point that technological advances are introduced which contribute to the development of sustainable port policies (Puertos del Estado, 2019).

The first actions taken by the Port Authorities of the Member States were transformed into projects such as ECO INFORMATION, by the Port Authority of Amsterdam, 1997, or the GREEN AWARD system of the Port of Rotterdam. In Spain, one of the first projects was ECOPORT, by the Port Authority of Valencia, whose motto is "towards a Port Community that respects the environment" (Autoridad Portuaria de Valencia, 2019; Peris-Mora, Orejas, Subirats, Ibáñez \& Álvarez, 2005).

From the perspective of the European Union, the intention is to comply with the sustainable development agreements of the United Nations. Although the first milestone in relation to sustainable development occurred in 1987 when the European Foundation for Environmental Education (FEEE) supported by the European Commission developed the Blue Flag Project within the "European Year of the Environment" to implement an environmental management system, an eco-label system and the management of beaches and marinas (Peris-Mora et al., 2005).

The importance of the sea for the European Union has led to a set of rules for each of the sectors related to the sea, such as maritime transport, aquaculture, fishing, security and surveillance, etc. The result (Sobrino, 2018) is a legal environment within which the European sectorial policies related to the sea and the oceans meet. At the same time, many authorities directly involved in each of the sectorial policies related to the sea were identified and, on occasions, these authorities presented conflicts due to the overlapping of different competences on the same ground. Undoubtedly, this situation calls for the integration of European policies in relation to the sea.

In 2005, the Commission includes the Integrated Maritime Policy in its strategic objectives for the period 2005-2009. In 2006, the Green Paper towards a future maritime policy of the Union: A European perspective on the oceans and seas is adopted, and in 2007, the proposal for an Integrated Maritime Policy for the Union, known as the Blue Book (European Commission, 2007) as well as its action plan were published (SEC (2007) 1278). Finally, Regulation 1255/2011 of the European Parliament and of the Council establishing a Support Program for the consolidation of the integrated maritime policy, gives life to a holistic approach for all Union policies related to the sea. Based on the idea that the Union can obtain greater benefits from the seas and oceans with less negative effects on the environment by coordinating its policies, the PMI covers fields as diverse as fisheries and aquaculture, transport and seaports, marine environment, marine research, marine energy, shipbuilding and related industries, maritime surveillance, maritime and coastal tourism, employment, the development of coastal regions and external relations in maritime matters (p. 6 ).

The objectives established in the framework of the PMI are based on six pillars:

- Maximize the sustainable use of oceans and seas to enable the growth of maritime regions and coastal regions.

-Create a knowledge and innovation base for maritime policy.

-Improve the quality of life in coastal regions.

-Promote the leadership of the Union in international maritime affairs.

- Improve the visibility of maritime Europe.

- Create internal coordination structures for maritime affairs and define the responsibilities and competences of coastal regions.

Based on these, there have been numerous Communications and Recommendations, including the strategy for maritime basins, in 2009 the first comprehensive strategy for the Baltic Sea region (Commission of the European Communities, 2009a), followed by better governance of the Mediterranean (Commission of the European Communities, 2009b), the Black Sea (Commission of the European Communities, 2007), Atlantic strategy (Commission of the European Communities, 2011) and active participation in the planning of the Arctic region (European Commission, 2016). 
One of the most important milestones in relation to sustainable development reached to date by the United Nations has been the 2030 Agenda, approved in 2015, where 17 objectives are set, with 169 goals of an integrated and indivisible nature that cover different economic, social and environmental sectors. It is articulated as a master plan to achieve a sustainable future for all, interrelating the objectives among themselves and incorporating the global challenges that we face every day, such as poverty, inequality, climate, environmental degradation, prosperity, peace and justice (Organización de las Naciones Unidas, 2019).

The first day of 2016 the 2030 Agenda for Sustainable Development will officially enter into effect that will set the tone for the next 15 years to build a fairer and more equitable world for the entire population, in addition to protecting the environment (Ban Ki-moon, 2016, p. 1).

It is not debatable that the increase in sustainability in the maritime transport sector is essential to achieve the Sustainable Development Goals, as well as the goals set in the Paris Agreement (United Nations, 2016). Maritime transport is one of the keys when it comes to caring for the environment, since approximately $80 \%$ of exported goods are transported by sea and it is estimated that it represents a quarter of greenhouse gas emissions.

However, the application of sustainable maritime transport solutions entails costs and requires additional resources. Therefore, it is important to increase investment, particularly through new sources and mechanisms, and to promote greater participation of the private sector, for example, through public-private partnerships that also incorporate sustainability and resilience criteria. The maritime sector is at a crossroads of new developments, particularly, innovations and new digital technologies (Conferencia de las Naciones Unidas sobre Comercio y Desarrollo [UNCTAD], 2019).

At the international level of maritime transport, the International Maritime Organization (IMO, 2017) has adopted a strategic plan for the period 2018-2023. This plan identifies the strategic directions on which IMO will focus for this period, where the opinions of all stakeholders will be guaranteed in their decision-making processes, paying special attention to the needs of developing countries (IMO, 2017).

\section{Sustainable port governance}

The Integrated Maritime Policy tries to favor cooperation of the authorities present in the transversal sectors related to the sea, among all the Member States, in addition to "maximizing sustainability". The purpose of this research is to analyze the institutional framework of port governance in order to evaluate the organization's performance via specific indicators. The achievements targeted by the new organizational framework must contribute to environmental sustainability within the field of maritime transport governance, and clarify its functions in favor of cohesion between the port governance of Member States through the use of shared strategies for the marine basins.

As part of the attempt to evaluate the best performance of the organization, we need to define which the points and factors are that must be taken into account and, therefore, which ports must have competences. We can cite as an example of application of the PMI in a specific port the case of the Port of Vigo ("Blue Growth Vigo"), where the main objectives position the port as: (i) innovative; (ii) green; (iii) connected, and (iv) inclusive (Autoridade Portuaria de Vigo [APV], 2019).

In particular, the green port is characterized as one that uses clean technology and implements processes that respect the environment. However, as Acciaro et al. (2014) point out, the concept of "green port", or environmentally friendly port, sometimes only translates into a need for compliance, since costs and legislation will be the main drivers of environmental strategies.

Therefore, there is a need for control and promotion of environmental strategies in relation to port governance, both of which have been nonexistent in Spain until now. The sustainability reports 
prepared by Puertos del Estado, specifically in relation to its present institutional dimension indicators, measure aspects such as: infrastructures, target markets, financial viability, institutional communication, operational efficiency or quality of services i.e. at no time do they refer to the actions that need to be taken or the objectives that need to be achieved by the institutions/organizations that make up the port system, or to how the achievement of those objectives will be measured.

Table 2 shows the green objectives to be met by each of the port governance bodies/institutions (Acciaro et al., 2014).

Table 2. The objectives of green ports in the new governance

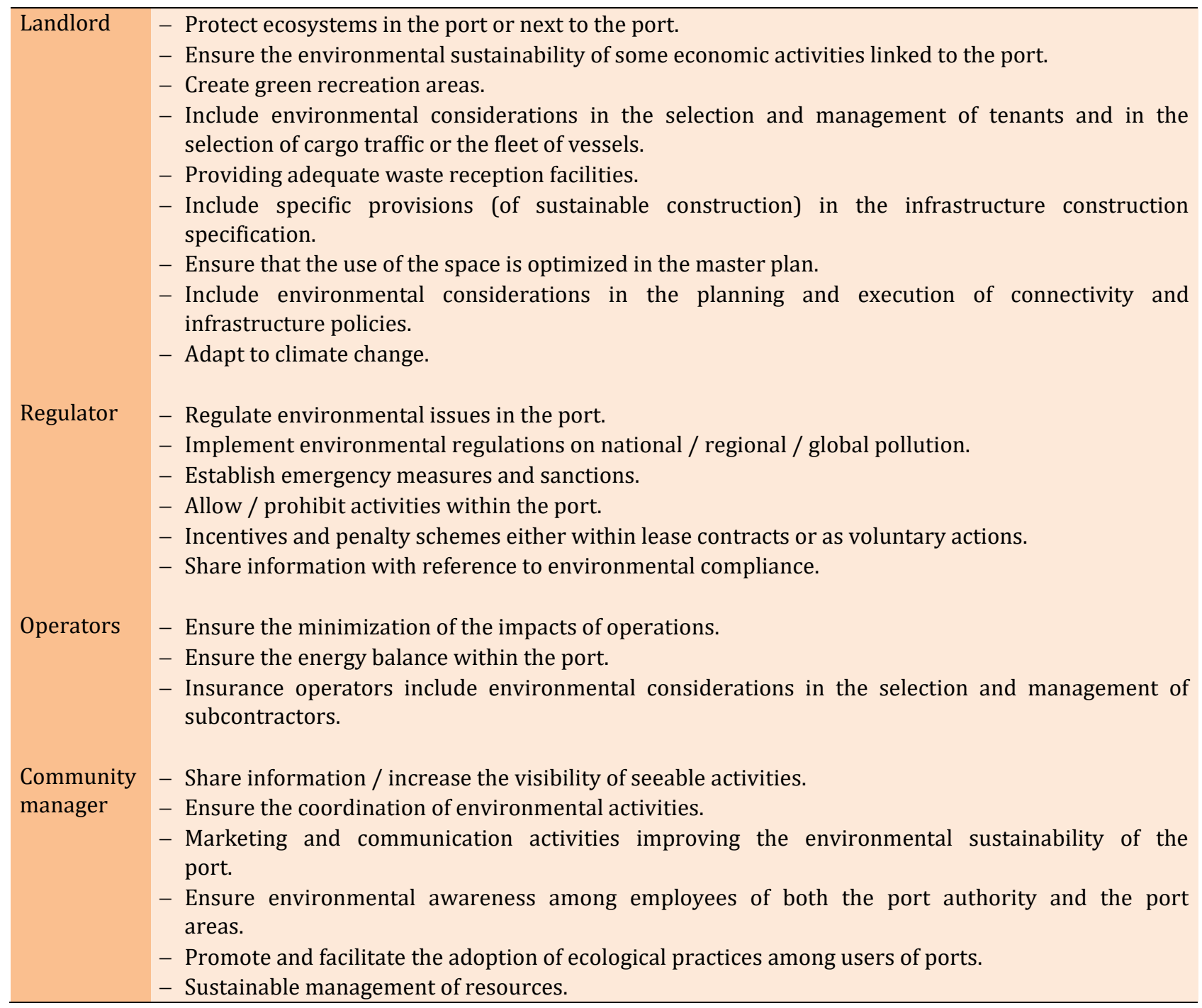

Source: Acciaro et al. (2014).

The port governance scheme in Spain has different institutions for each of the functions coined by Verhoeven (2010). The landlord is the competent Port Authority, the regulator is the Ministry of Development, the operator is in charge of the functioning of port operations. and can be a public, private or public-private institution; and, finally, the function of community manager is carried out by State Ports. 


\section{Ferrol-San Cibrao Port authority vs Vigo port authority}

The Port Authority of Vigo has been highlighted as the leading port when implementing the initiatives of the Integrated Maritime Policy. However, as said before, special emphasis should be placed on the need to monitor the measures implemented via indicators for a later analysis to establish how they favor the efficiency and sustainability of the port system.

First, we try to compare two port authorities that are geographically located close to each other and which have developed a strong interest in port sustainability (port memories). Hence, we will compare two Galician Port Authorities, Ferrol-San Cibrao, and Vigo. Figure 1 shows the total traffic moved in both ports since 1990, expressed in tons.

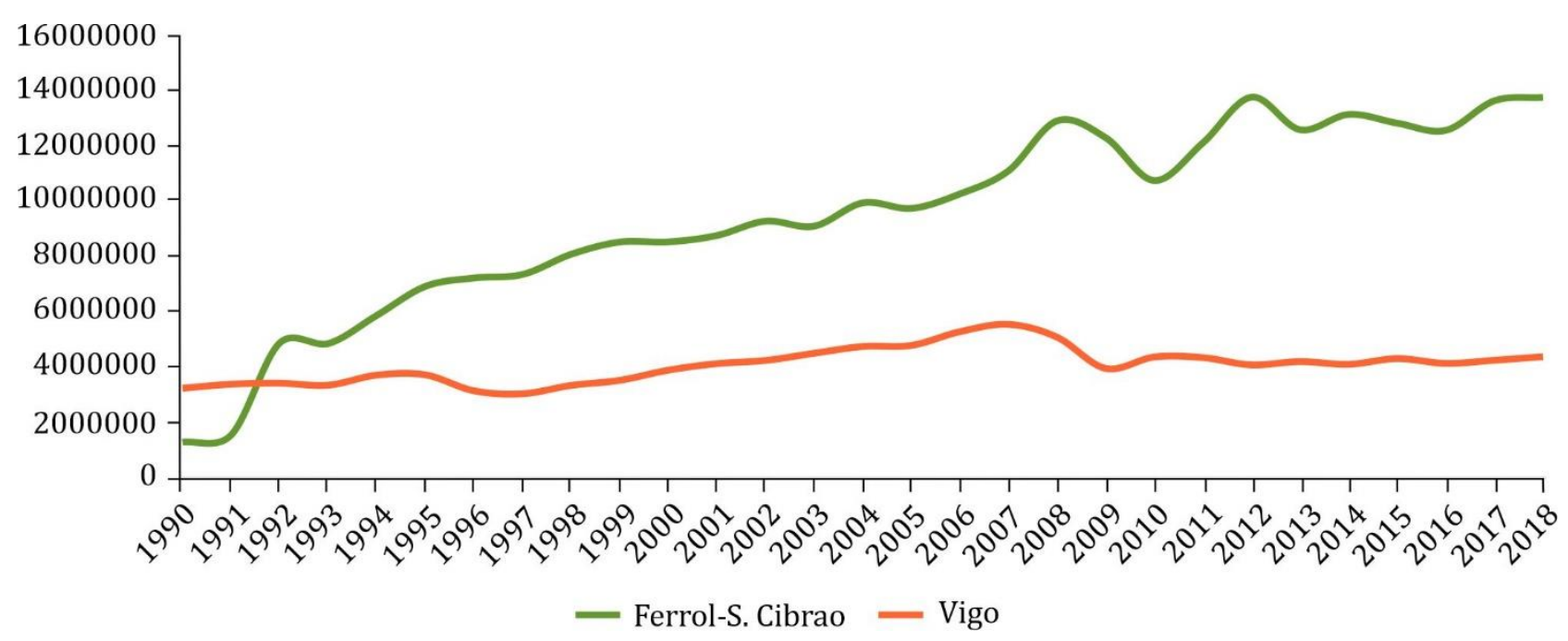

Figure 1. Total traffic moved (MT). Source: data Puertos del Estado (2019), own elaboration.

Taking into account the tons handled, and in order to build indicators to evaluate port governance, special focus is needed on the Port Authority, which, according to Verhoven (2010), fulfills the functions of landlord in the port governance system. Figures 2 and 3 show the flow charts of the Port Authorities of Ferrol-San Cibrao and Vigo with some indicators that were constructed ad hoc to evaluate the governance of these two port authorities.

The organization of the Port Authorities is led by a president and a director, and it consists of several areas, departments, and divisions. If we compare the number of areas, departments, and divisions, it can be seen that, in both cases, there are two areas, although they deal with different matters. In the case of the Port Authority Ferrol-San Cibrao there are 6 departments and 7 divisions, while in the Port Authority of Vigo there are 8 departments and 8 divisions.

A benchmarking methodology will be used i.e. the construction of indicators to evaluate the port performance evolution. If we build an indicator that relates the cargo volume handled in the ports with the number of levels in the organization chart, we can see two versions:

First, the relationship between tons and number of areas, departments and divisions:

$$
\text { Indicator } 1 \text { = tons } / \text { (no. of areas + no. of departments + no. of divisions) }
$$

Second, the relationship between tons and the number of areas, departments, and weighted divisions. The weightings have been carried out considering the hierarchical level of each organization chart. Therefore, the greater the weighting, the higher the level of responsibility:

$$
\text { Indicator } 2 \text { = tons } /(\text { no. of areas } * 3+\text { no. of departments } * 2+\text { no. of divisions } * 1 \text { ) }
$$




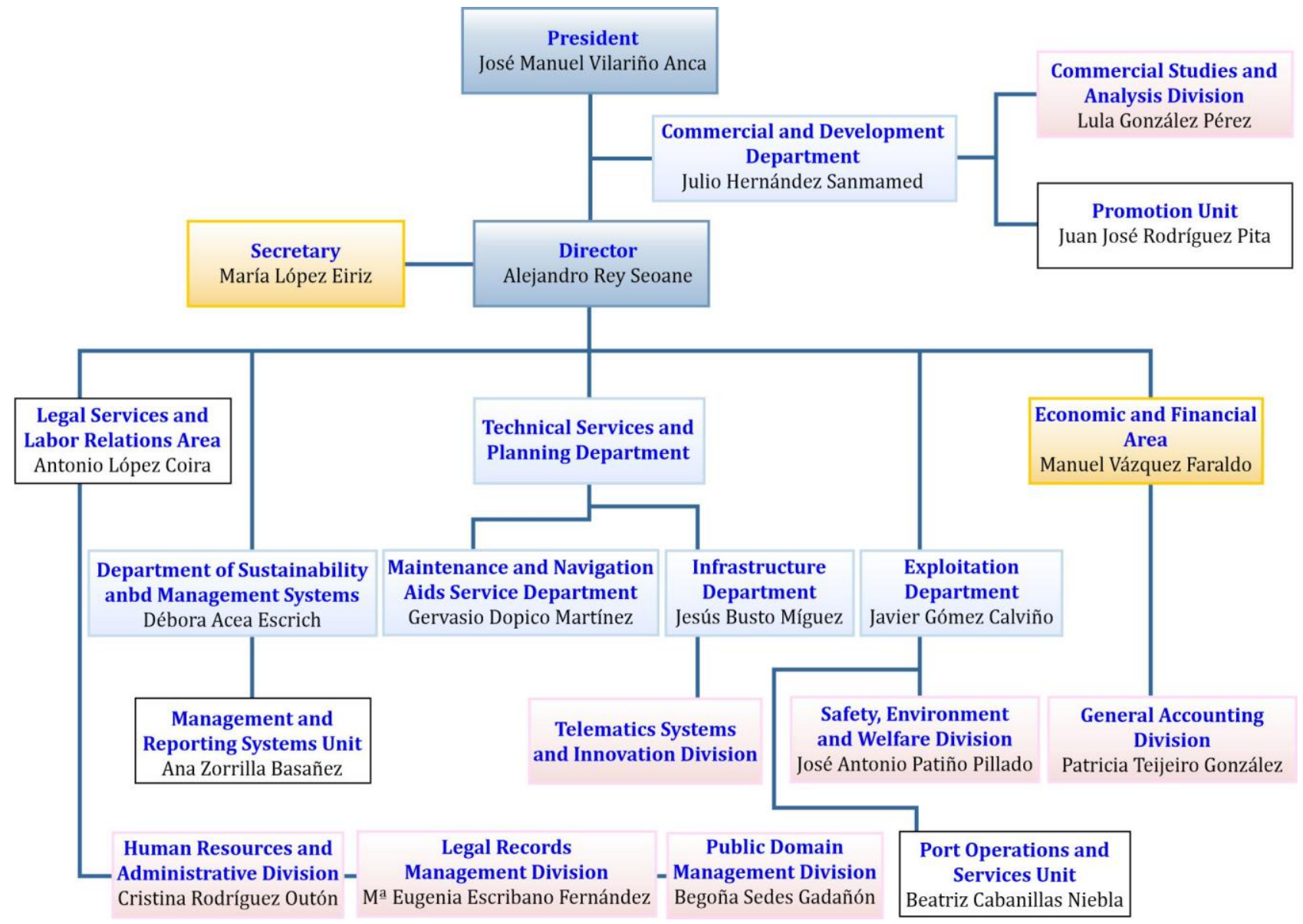

Figure 2. Ferrol-San Cibrao Port AuthorityOrganization. Source: Autoridad Portuaria de Ferrol-San Cibrao (2019).

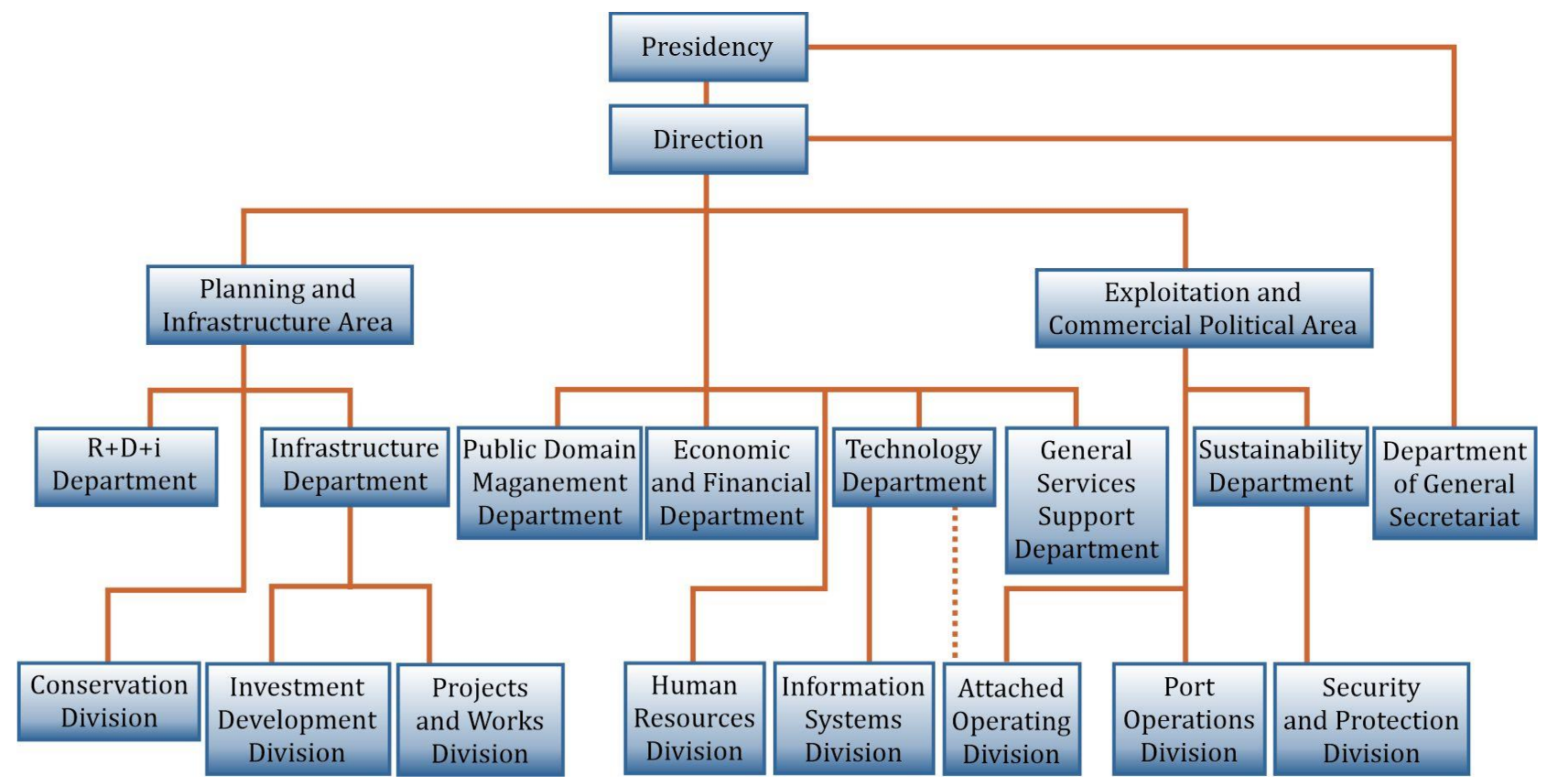

Figure 3. Vigo Port Authority Organization. Source: Autoridad Portuaria de Vigo (2019). 
In Figure 4, and under the hypothesis that the organigram of each port authority has been the same throughout the period analyzed, it is observed that Indicator 2, which carries out a weighting of each level within the organization, maintains almost constant values between 1990 and 2018 with respect to total traffic. The volumes of the Port Authority of Ferrol-San Cibrao are larger than those of Vigo. The results show that the Ferrol Port Authority has more tons assigned to its organizational level compared to that of Vigo.

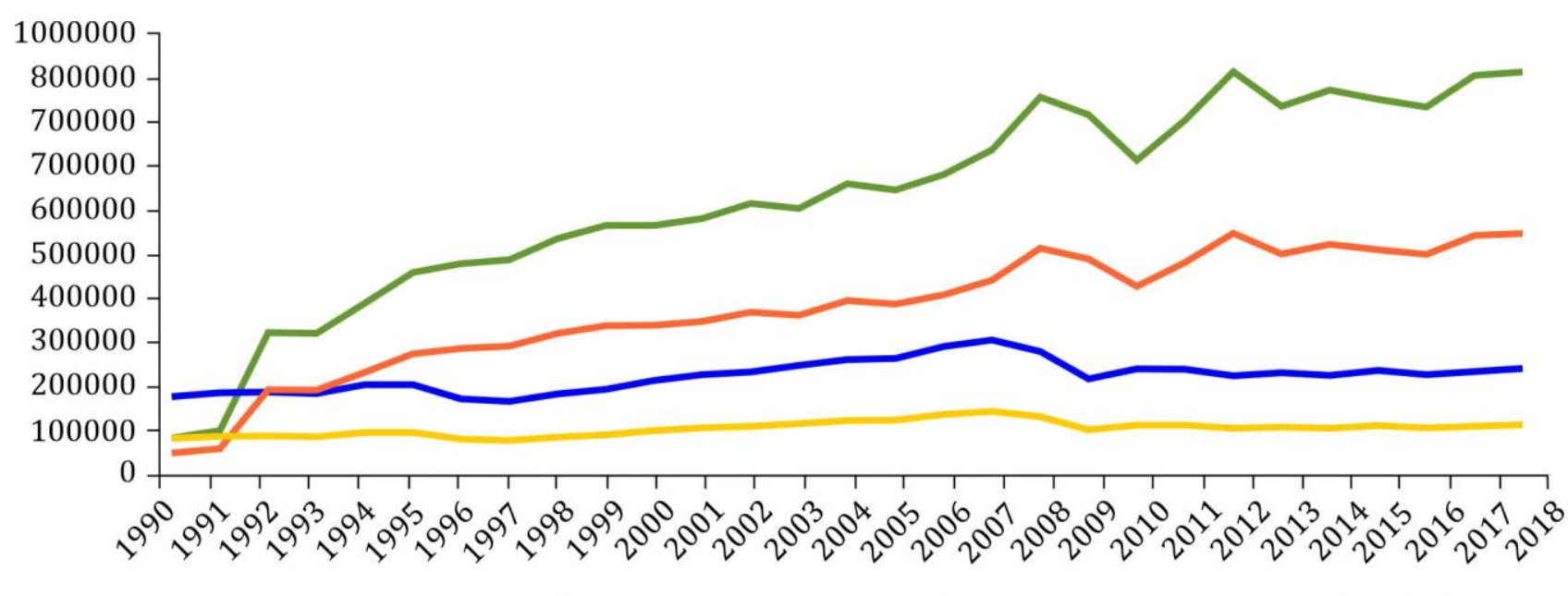

- Ferrol-S. Cibrao Indicator 1 - Vigo Indicator 1 - Ferrol-S. Cibrao Indicator 2 - Vigo Indicator 2

Figure 4. Indicators of port governance for the different Port Authorities: tons per level of governance. Source: own elaboration.

\section{Conclusions}

The Integrated Maritime Policy of the European Union is a declaration of intentions on the need to coordinate all the regulations that affect the transversal sectors related to the sea, given their importance and strategic preponderance for the continent. Although it is true that it is a complex and ambitious project, it is based on an initial idea of coordination, especially of public authorities or agents that sometimes collide in the exercise of their powers.

This research tries to structure a system of port governance, related to maritime transport, but which is no more than the structure of the institutions that are part of the supply chain of merchandise entering the territory by sea. On the one hand, it is necessary to define the levels and actions/functions of each institution or body. To do this, the structure of Verhoeven (2010) is followed, which proposes a structure based on functions and proposes a series of actions that each agency has to carry out in order to strive towards a competitive and efficient system.

On the other, one of the basic or essential pillars of the Integrated Maritime Policy is sustainability, which in maritime transport, to date, has resulted in increased safety of ships (double hull) and reduction of greenhouse gas emissions (goal to be achieved in the year 2050). However, as Acciaro et al. (2014) pointed out, to create a truly "green port" it is necessary to count on an environmental strategy based on cost incentives and on avoiding penalties, , which is why they propose a series of actions to be complied with by each port governance organism. Indicators need to be developed based on these green objectives with the commitment of guaranteeing sustainability and, at the same time, incorporating technological innovations to promote efficiency and competitiveness. In this research, two indicators are presented which relate total port traffic to the organization system of the Port Authority, which, in the Spanish port system, plays the role of landlord (Verhoeven, 2010). 
Finally, one of the most complex steps is to align the systems of governance by sea basins i.e. to coordinate the different competent organizations within the Member States in the decision-making process, as well as among those responsible for controlling the objectives established by the Union.

\subsection{Limitations and possible future research lines}

The main limitation in this research is the availability of economic data. If the used indicators are constructed based on actual cost and revenue figures, an analysis with more information and with more robust conclusions will be made.

\section{References}

Acciaro, M., Vanelslander, T., Sys, C., Ferrari, C., Roumboutsos, A., Giuliano, G., \& Kapros, S. (2014). Environmental sustainability in seaports: A framework for successful innovation. Maritime Policy \& Management, 41(5), 480500. DOI: https://doi.org/10.1080/03088839.2014.932926

Autoridad Portuaria de Valencia. (2019). Proyecto ECOPORT. Valencia: Autoridad Portuaria de Valencia. Retrieved from: https://ecoport.valenciaport.com/SitePages/Portada.aspx

Autoridade Portuaria de Vigo (2019). Autoridad Portuaria de Vigo: Blue growth Vigo. Retrieved from: http://www.bluegrowthvigo.eu/

Autoridade Portuaria Ferrol-San Cibrao. (2019). https://www.apfsc.com/

Baird, A. (1999). Analysis of private seaport development: the port of Felixstowe. Transport Policy, 6(2), 109-122. DOI: https://doi.org/10.1016/S0967-070X(99)00012-8

Baird, A. J. (1995). Privatisation of trust ports in the United Kingdom: Review and analysis of the first sales. Transport Policy, 2(2), 135-143. DOI: https://doi.org/10.1016/0967-070X(95)91993-T

Baird, A. J. (2000). Port privatisation: Objectives, extent, process, and the UK experience. International Journal of Maritime Economics, 2(3), 177-194. DOI: https://doi.org/10.1057/ijme.2000.16

Baird, A. J., \& Valentine, V. F. (2006). Port privatisation in the United Kingdom. Research in Transportation Economics, 17, 55-84. DOI: https://doi.org/10.1016/S0739-8859(06)17003-1

Baltazar, R., \& Brooks, M. R. (2001). The governance of port devolution: A tale of two countries. In World Conference on Transport Research (pp. 22-27).

Retrieved from: http://citeseerx.ist.psu.edu/viewdoc/download?doi=10.1.1.195.460\&rep=rep1\&type=pdf

Ki-moon, B. (2016). Sustainability-engaging future generations now. The Lancet, 387(10036), 2356-2358. DOI: https://doi.org/10.1016/S0140-6736(16)30271-9

Bouchartar, H., Hajbi, A., \& Abbar, H. (2011). Governance of the maritime and port sector: Morocco as example. Journal of US. China Public Administration, 8(7), 763-773.

Brooks, M. (2006). Port devolution and governance in Canada. Research in Transportation Economics, 17, $237-$ 257. DOI: https://doi.org/10.1016/S0739-8859(06)17011-0

Brooks, M., \& Cullinane, K. (2007). Devolution, port governance and port performance. Research in Transportation Economic, 17, 405-435.

Brunt, B. (2000). Ireland's seaport system. Tijdschrift voor Economische en Sociale Geografie, 91(2), 159-175.

Cabrera, M., Suárez-Alemán, A., \& Trujillo, L. (2015). Public-private partnerships in Spanish Ports: Current status and future prospects. Utilities Policy, 32,1-11. DOI: https://doi.org/10.1016/i.jup.2014.11.002

Caldeirinha, V., Augusto F., \& Figueiredo da Cunha, S. (2017). Government policies and Portuguese port governance in the period from 2005 to 2015. Research in Transportation Business \& Management, 22, 11-20. DOI: https://doi.org/10.1016/j.rtbm.2016.11.004

Castillo-Manzano, J. I., \& Asencio-Flores, J. P. (2012). Competition between new port governance models on the Iberian Peninsula. Transport Reviews, 32(4), 519-537. DOI: https://doi.org/10.1080/01441647.2012.662538

Chen, P., Pateman, H., \& Sakalayen, Q. (2017). The latest trend in Australian port privatisation: Drivers, processes and impacts. Research in Transportation Business \& Management, 22, 201-213. DOI: https://doi.org/10.1016/j.rtbm.2016.10.005

Comisión de las Comunidades Europeas. (2007). Comunicación de la Comisión al Consejo y al Parlamento Europeo. La sinergia del Mar Negro, una nueva iniciativa de cooperación regional. COM(2007)160 final. Bruselas, Bélgica: Comisión de las Comunidades Europeas. Retrieved from: https://eur-lex.europa.eu/legalcontent/ES/TXT/PDF/?uri=CELEX:52007DC0160\&from=EN 
Comisión Europea. (2013). Comunicación de la Comisión de 23 de mayo de 2013. Puertos: motor de crecimiento. COM(2013)295 final. Bruselas, Bélgica: Comisión Europea. Retrieved from: http://www.puertos.es/eses/medioambiente/Documents/Puertos\%20Motor\%20de\%20Crecimiento.Pdf

Commission of the European Communities. (2009a). Communication from the Commission to the European Parliament, the Council, the European Economic and Social Committee and the Committee of the Regions concerning the European Union Strategy for the Baltic Sea Region. \{SEC(2009)702\} \{SEC(2009)703\} $\{\operatorname{SEC}(2009) 712\}$. COM(2009)248 final. Brussels, Belgium: Commission of the European Communities. Retrieved from:

https://eur-lex.europa.eu/legal-content/EN/TXT/PDF/?uri=CELEX:52009DC0248\&from=EN

Commission of the European Communities. (2009b). Communication from the Commission to the European Parliament, the Council, the European Economic and Social Committee and the Committee of the Regions. Developing the international dimension of the Integrated Maritime Policy of the European Union. COM(2009) 536 final. Brussels, Belgium: Commission of the European Communities.

Retrieved from: https://eur-lex.europa.eu/legal-content/EN/TXT/PDF/?uri=CELEX:52009DC0536\&from=GA

Commission of the European Communities. (2011). Communication from the Commission to the European Parliament, the Council, the European Economic and Social Committee and the Committee of the Regions. Developing a Maritime Strategy for the Atlantic Ocean Area. COM(2011)782 final. Brussels, Belgium: Commission of the European Communities. Retrieved from:

https://eur-lex.europa.eu/legal-content/EN/TXT/PDF/?uri=CELEX:52011DC0782\&from=EN

Conferencia de las Naciones Unidas sobre Comercio y Desarrollo. (2019). El transporte de mercancías sostenible en apoyo de la Agenda 2030 para el desarrollo sostenible. Ginebra, Suiza: UNCTAD.

Retrieved from: https://unctad.org/system/files/official-document/cimem7d17 es.pdf

Cullinane, K., \& Song, D. W. (1998). Container terminals in South Korea: problems and panaceas. Maritime Policy \& Managements, 25(1), 63-80. DOI: https://doi.org/10.1080/03088839800000045

Cullinane, K., Teng, Y., \& Wang, T. F. (2005). Port competition between Shanghai and Ningbo. Maritime Policy \& Management, 32(4), 331-346. DOI: https://doi.org/10.1080/03088830500300438

De Langen, P. W., \& Pallis, A. A. (2007). Entry barriers in seaports. Maritime Policy \& Management, 34(5), 427440. DOI: https://doi.org/10.1080/03088830701585134

De Langen, P. W., \& van der Lugt, L. M. (2006). Governance structures of port authorities in the Netherlands. Research in Transportation Economics, 17, 109-137. DOI: https://doi.org/10.1016/S0739-8859(06)17005-5

De Langen, P. W., \& van der Lugt, L. M. (2017). Institutional reforms of port authorities in the Netherlands; the establishment of port development companies. Research in Transportation Business \& Management, 22, 108113. DOI: https://doi.org/10.1016/j.rtbm.2016.12.007

Debrie, J. (2011). Difference tiers of government in port governance: Some general remarks on the institutional geography of ports in Europe and Canada. In 12th World Conference on Transport Research. Lisbon, Portugal. July 2010. Retrieved from: https://hal.archives-ouvertes.fr/hal-00615146/document

Debrie, J., Lacoste, R., \& Magnan, M. (2017). From national reforms to local compromises: The evolution of France's model for port management, 2004-2015. Research in Transportation Business \& Management, 22, 114-122. DOI: https://doi.org/10.1016/j.rtbm.2016.12.006

Dooms, M., \& Farrell, S. (2017). Lions or gazelles? The past, present and future of African port authorities: The case of East Africa. Research in Transportation Business \& Management, 22, 135-152. DOI: https://doi.org/10.1016/i.rtbm.2016.12.002

Esmer, S., \& Duru, O. (2017). Port governance in Turkey: The age of the global terminal operators. Research in Transportation Business \& Management, 22, 214-223. DOI: https://doi.org/10.1016/j.rtbm.2016.12.001

European Commission. (2007). Communication from the Commission to the European Parliament, the Council, the European Economic and Social Committee and the Committee of the Regions - An Integrated Maritime Policy for the European Union. $\{\mathrm{COM}(2007) 574$ final)\} \{SEC(2007)1278\} \{SEC(2007)1279\} \{SEC(2007)1280\} \{SEC(2007)1283\}. Brusels, Belgium: European Commission. Retrieved from: https://eur-lex.europa.eu/legal-content/EN/TXT/?uri=CELEX:52007DC0575

European Commission. (2016). Joint Communication to the European Parliament and the Council. An integrated European Union policy for the Arctic. JOIN(2016)21 final. Brussels, Belgium: European Commission.

Retrieved from: https://eur-lex.europa.eu/legal-content/EN/TXT/PDF/?uri=CELEX:52016JC0021\&from=EN

Everett, S., \& Robinson, R. (2006). Port reform: The Australian experience. Research in Transportation Economics, 17, 259-284. DOI: https://doi.org/10.1016/S0739-8859(06)17012-2 
Fawcett, J. (2006). Port governance and privatization in the United States: Public ownership and private operation. Research in Transportation Economics, 17, 207-235.

DOI: https://doi.org/10.1016/S0739-8859(06)17010-9

Ferrari, C., Tei, A., \& Merk, O. (2015). The governance and regulation of ports: The case of Italy. Paris, France: International Transport Forum. Discussion Paper No. 2015-01. Retrieved from: https://www.itfoecd.org/sites/default/files/docs/dp201501.pdf

Fleming, D. K., \& Baird, A. J. (1999). Comment some reflections on port competition in the United States and Western Europe. Maritime Policy \& Management, 26(4), 383-394.

DOI: https://doi.org/10.1080/030888399286817

Frémont, A., \& Ducruet, C. (2005). The emergence of a mega-port-from the global to the local, The Case of Busan. Tijdschriftvoor Economischeen Sociale Geografie, 96(4), 421-432.

Retrieved from: https://halshs.archives-ouvertes.fr/halshs-00458055v2/document

Galvão, C. B., Robles, L. T., \& Cardoso, G. (2017). 20 years of port reform in Brazil: Insights into the reform process. Research in Transportation Business \& Management, 22, 153-160. DOI: https://doi.org/10.1016/j.rtbm.2017.01.002

Ghashat, H. M., \& Cullinane, K. P. (2013). The future governance structure of Libya's container ports: A survey of stakeholder attitudes. Research in Transportation Business \& Management, 8, 7-16. DOI: https://doi.org/10.1016/j.rtbm.2013.03.005

González Laxe, F. (2012). El marco regulatorio de los puertos españoles: resultados y conectividad internacional. Economía Industrial, 386, 27-38.

Retrieved from: https://dialnet.unirioja.es/servlet/articulo?codigo=4155936

González-Laxe, F., Freire-Seoane, M. J., \& Pais-Montes, C. (2012). Maritime degree, centrality and vulnerability: port hierarchies and emerging areas in containerized transport (2008-2010). Journal of Transport Geography, 24, 33-44. DOI: https://doi.org/10.1016/i.jtrangeo.2012.06.005

González-Laxe, F.; Sánchez, R., \& García-Alonso, L. (2016). The adaptation process in port governance: The case of the Latin countries in South America and Europe. Journal of Shipping and Trade, 1(1), 1-20. DOI: https://doi.org/10.1186/s41072-016-0018-y

Goss, R. (1998). British ports policies since 1945. Journal of Transport Economics and Policy, 32(1), 51-71.

Goulielmos, A. M. (1999). Deregulation in major Greek ports: The way it has to be done. International Journal of Transport Economics/Rivista Internazionale di Economia dei Trasporti, 26(1), 121-148.

Retrieved from: https://www.jstor.org/stable/42747359

Goulielmos, A. M. (2000). European policy on port environmental protection. Global Nest: The International Journal, 2(2), 189-197.

Retrieved from: https://journal.gnest.org/sites/default/files/Journal\%20Papers/07 goulielmos.pdf

Gumede, S., \& Chasomeris, M. (2012). Port governance in South Africa. Interdisciplinary Journal of Economics and Business Law, 1(4), 82-98.

Retrieved from: https://www.researchgate.net/publication/269687229 Port Governance in South Africa

Havenga, J., Simpson, Z., \& Goedhals-Gerber, L. (2017). International trade logistics costs in South Africa: Informing the port reform agenda. Research in Transportation Business \& Management, 22, 263-275. DOI: https://doi.org/10.1016/i.rtbm.2016.08.006

Heaver, T., Meersman, H., Moglia, F., \& Van De Voorde, E, (2000). Do mergers and alliances influence European shipping and port competition? Maritime Policy \& Management, 27(4), 363-373. DOI: https://doi.org/10.1080/030888300416559

Hoffman, J. (1999, September). After the Latin American ports privatization: The emergence of a 'Latin American model'. In Fourth PdI World Port Privatization Conference. London, England.

Huff, W. (1997). The economic growth of Singapore: Trade and development in the twentieth century, Cambridge, England: Cambridge University Press.

International Maritime Organization. (2017). Resolution A.1110(30) adopted on 6 December 2017 (Agenda item 7) Strategic plan for the organization for the six-year period 2018 to 2023. London, England: International Maritime Organization.

Retrieved from: http://www.imo.org/en/About/strategy/Documents/A\%2030-RES.1110.pdf

Ircha, M. (2001). North American port reform: The Canadian and American experience. International Journal of Maritime Economics, 3(2), 198-220. DOI: https://doi.org/10.1057/palgrave.ijme.9100011

Knatz, G. (2017). How competition is driving change in port governance, strategic decision-making and government policy in the United States, Research in Transportation Business \& Management, 22, 67-77.

DOI: https://doi.org/10.1016/j.rtbm.2016.08.003 
Lee, E. S., \& Song, D. W. (2010). Knowledge management for maritime logistics value: discussing conceptual issues. Maritime Policy \& Management, 37(6), 563-583. DOI: https://doi.org/10.1080/03088839.2010.514959

Li, K. X., Luo, M., \& Yang, J. (2012). Container port systems in China and the USA: A comparative study. Maritime Policy \& Management, 39(5), 461-478. DOI: https://doi.org/10.1080/03088839.2012.705032

Marques, R., \& Fonseca, A. (2010). Market structure, privatisation and regulation of Portuguese seaports. Maritime Policy \& Management, 37(2), 145-161. DOI: https://doi.org/10.1080/03088830903533791

Martínez-Budría, E., Díaz-Armas, R., Navarro-Ibáñez, M., \& Ravelo-Mesa, T. (1999). A study of the efficiency of Spanish port authorities using data envelopment analysis. International Journal of Transport Economics/Rivista internazionale di economia dei trasporti, 26(2), 237-253. Retrieved from:

https://www.researchgate.net/publication/276204733 A Study of the Efficiency of Spanish Port Authoriti es Using Data Envelopment Analysis

Meersman, H., Van de Voorde, E., \& Vanelslander, T. (2006). Fighting for money, investments and capacity: Port governance and devolution in Belgium., Research in Transportation Economics, 17, 85-107. DOI: https://doi.org/10.1016/S0739-8859(06)17004-3

Montero, F. J. (2004). Panamanian maritime sector managements. Marine Policy, 28(4), 283-295. DOI: https://doi.org/10.1016/i.marpol.2003.09.007

Montero, F. J. (2005). Panama Canal management. Marine Policy, 29(1), 25-37. DOI: https://doi.org/10.1016/j.marpol.2004.02.001

Montero, F. J. (2006). Port privatization in Panama. Marine Policy, 30(5), 483-495. DOI: https://doi.org/10.1016/j.marpol.2005.06.017

Notteboom, T. (2010). Concentration and the formation of multi-port gateway regions in the European container port system: An update. Journal of Transport Geography, 18(4), 567-583.

DOI: https://doi.org/10.1016/i.jtrangeo.2010.03.003

Nikolopoulou, A. et al. (2019). Sustainable port development: Towards the Physical Internet concept. In $6^{\text {th }}$ International Physical Internet Conference. London, United Kingdom. 9-11 July 2019. Retrieved from: https://cris.vtt.fi/en/publications/sustainable-port-development-towards-the-physical-internet-concep

Notteboom, T., De Langen, P., \& Jacobs, W. (2013). Institutional plasticity and path dependence in seaports: interactions between institutions, port governance reforms and port authority routines. Journal of Transport Geography, 27, 26-35. DOI: https://doi.org/10.1016/j.jtrangeo.2012.05.002

Notteboom, T., \& Neyens, K. (2017). The future of port logistics. Meeting the challenges of supply chain integration. Brussels, Belgium: ING Bannk. Retrieved from:

http://www.portexpertise.com/wp-content/uploads/2017/07/ING-the-future-of-port-logistics.pdf

Notteboom, T., \& Zhongzhen Y. (2017). Port governance in China since 2004: Institutional layering and the growing impact of broader policies. Research in Transportation Business \& Management, 22, 184-200. DOI: https://doi.org/10.1016/j.rtbm.2016.09.002

Oral, E. Z., Kisi, H., Cerit, A. G., Tuna, O., \& Esmer, S. (2006). Port governance in Turkey. Research in Transportation Economics, 17, 71-184. DOI: https://doi.org/10.1016/S0739-8859(06)17008-0

Organización de las Naciones Unidas. (2019). Naciones Unidas: objetivos de desarrollo sostenible. New YorK, NY: Organización de las Naciones Unidas.

Retrieved from: https://www.un.org/sustainabledevelopment/es/sustainable-development-goals/

Pallis, A. A. (2006). Port governance in Greece. Research in Transportation Economics, 17, 155-169. DOI: https://doi.org/10.1016/S0739-8859(06)17007-9

Pallis, A. A., \& Syriopoulos, T. (2007). Port governance models: Financial evaluation of Greek port restructuring. Transport Policy, 14(3), 232-246. DOI: https://doi.org/10.1016/j.tranpol.2007.03.002

Pallis, A. A., \& Vaggelas, G. K. (2017). A Greek prototype of port governance. Research in Transportation Business \& Management, 22, 49-57. DOI: https://doi.org/10.1016/j.rtbm.2016.12.003

Pallis, A. A., Vitsounis, T. K., \& De Langen, P. W. (2010). Port economics, policy and management: Review of an emerging research field. Transport Reviews, 30(1), 115-161. DOI: https://doi.org/10.1080/01441640902843208

Parola, F., Ferrari, C., Tei, A., Satta, G., \& Musso, E. (2017). Dealing with multi-scalar embeddedness and institutional divergence: Evidence from the renovation of Italian port governance. Research in Transportation Business \& Management, 22, 89-99. DOI: https://doi.org/10.1016/j.rtbm.2016.12.005

Parola, F., Tei, A. \& Ferrari, C. (2012). Managing port concessions: Evidence from Italy. Maritime Policy \& Management, 39(1), 45-61. DOI: https://doi.org/10.1080/03088839.2011.642312 
Peris-Mora, E., Orejas, J. D., Subirats, A., Ibáñez, S., \& Álvarez, P. (2005). Development of a system of indicators for sustainable port management. Marine Pollution Bulletin, 50(12), 1649-1660.

DOI: https://doi.org/10.1016/j.marpolbul.2005.06.048

Pettit, S. J., \& Beresford, A. K. C. (2008). An assessment of long-term United Kingdom port performance: A regional perspective. Maritime Economics \& Logistics, 10(1-2), 53-74.

DOI: https://doi.org/10.1057/palgrave.mel.9100191

Psaraftis, H. N. (2005). EU ports policy: Where do we go from here? Maritime Economics \& Logistics, 7(1), 73-82. DOI: https://doi.org/10.1057/palgrave.mel.9100125

Puertos del Estado. (2019). Código de conducta ambiental ESPO. Madrid: Ministerio de Transportes, Movilidad y Agenda Urbana. Puertos del Estado.

Retrieved from: http://www.puertos.es/es-es/medioambiente/Paginas/ESPO.aspx

Rodrigue, J. P. (2017). The governance of intermediacy: The insertion of Panama in the global liner shipping network. Research in Transportation Business \& Management, 22, 21-26.

DOI: https://doi.org/10.1016/j.rtbm.2016.11.005

Rodrigue, J. P., Comtois, C., \& Slack, B. (2013). The geography of transport systems. London, England: Routledge. DOI: https://doi.org/10.4324/9781315618159

Sánchez, R. J., \& Wilmsmeier, G. (2006). The river plate basin-A comparison of port devolution processes on the East Coast of South America. Research in Transportation Economics, 17, 185-205.

DOI: https://doi.org/10.1016/S0739-8859(06)17009-2

Sherman, R. B. (2000). Seaport governance in the United States and Canada. Alexandria, VA: American Association of Port Authorities.

Shinohara, M. (2017). Characteristics of Japanese port policy: Strategic ports and policy dilemma. Research in Transportation Business \& Management, 22, 100-107. DOI: https://doi.org/10.1016/j.rtbm.2016.08.005

Sobrino H, J. M. (2018). El mar y la UE: la necesidad de una política marítima integrada. Revista de Derecho Comunitario Europeo, 22(61), 835-849. DOI: https://doi.org/10.18042/cepc/rdce.61.01

Song, D. W., \& Lee, S. W. (2006). Port governance in Korea. Research in Transportation Economics, 17, $357-375$. DOI: https://doi.org/10.1016/S0739-8859(06)17016-X

Song, D. W., \& Lee, S. W. (2017). Port governance in Korea: Revisited. Research in Transportation Business \& Management, 22, 27-37. DOI: https://doi.org/10.1016/j.rtbm.2016.11.002

Togan, S. (2009). Liberalization of transport services in Egypt, Jordan and Morocco. Washington DC, WA: World Bank.

Tseng, P. H., \& Pilcher, N. (2017). Port governance in Taiwan: How hypocrisy helps meet aspirations of change. Research in Transportation Business \& Management, 22, 38-48.

DOI: https://doi.org/10.1016/j.rtbm.2016.07.003

United Nations. (2016). Paris agreement. New York, NY: United Nations. Retrieved from: https://unfccc.int/files/essential background/convention/application/pdf/english_paris agreement.pdf

Ungo, R., \& Sabonge, R. (2012). A competitive analysis of Panama Canal routes. Maritime Policy \& Managements, 39(6), 555-570. DOI: https://doi.org/10.1080/03088839.2012.728727

Valleri, M., Lamonarca, M., \& Papa, P. (2006). Port governance in Italy. Research in Transportation Economics, 17, 139-153. DOI: https://doi.org/10.1016/S0739-8859(06)17006-7

van de Voorde, E., \& Verhoeven, P. (2017). Port governance and policy changes in Belgium 2006-2016: a comprehensive assessment of process and impact. Research in Transportation Business \& Management, 22, 123-134. DOI: https://doi.org/10.1016/j.rtbm.2016.12.004

Verhoeven, P. (2010). A review of port authority functions: towards a renaissance? Maritime Policy \& Management, 37(3), 247-270. DOI: https://doi.org/10.1080/03088831003700645

Verhoeven, P. (2011). European port governance-Report of an enquiry into the current governance of European seaports. The ESPO Fact-Finding Report. Brussels, Belgium: European Sea Ports Organisation. Retrieved from: https://www.espo.be/media/espopublications/espofactfindingreport2010.pdf

Villa, J. C (2017). Port reform in Mexico: 1993-2015. Research in Transportation Business \& Management, 22, 232238. DOI: https://doi.org/10.1016/j.rtbm.2016.11.003

Wang, J. J., Ng, A. K. Y., \& Olivier, D. (2004). Port governance in China: a review of policies in an era of internationalizing port management practices. Transport Policy, 11(3), 237-250. DOI: https://doi.org/10.1016/j.tranpol.2003.11.003

Wilmsmeier, G., \& Monios, J. (2016). Institutional structure and agency in the governance of spatial diversification of port system evolution in Latin America. Journal of Transport Geography, 51, 294-307.

DOI: https://doi.org/10.1016/i.jtrangeo.2015.02.004 
Wilmsmeier, G., \& Sánchez R. (2017). Evolution of national port governance and interport competition in Chile. Research in Transportation Business \& Management, 22, 171-183.

DOI: https://doi.org/10.1016/j.rtbm.2017.01.001

World Bank. (2007). Port reform: Toolkit. Second Edition. Washington DC, WA: World Bank.

Xiao, Z., \& Lam, J. S. L. (2017). A systems framework for the sustainable development of a Port City: A case study of Singapore's policies. Research in Transportation Business \& Management, 22, 255-262. DOI: https://doi.org/10.1016/j.rtbm.2016.10.003

Zurek, J. (1997). The privatization of Polish port-the present situation and outlook for the future. Maritime Policy \& Management, 24(3), 291-297. DOI: https://doi.org/10.1080/03088839700000032 